\title{
An Empirical Analysis of the Common Factors Influencing the Sharing and Green Economies
}

\author{
Cristina Veith ${ }^{1, *(\mathbb{D}}$, Simona Nicoleta Vasilache ${ }^{2}$, Carmen Nadia Ciocoiu ${ }^{1} \mathbb{D}$, Andreea Chițimiea ${ }^{1}$, \\ Mihaela Minciu ${ }^{1}$, Andreea-Mariana Manta ${ }^{1}$ and Iyad Isbaita ${ }^{1}$
}

1 Department of Management, Bucharest University of Economic Studies, 6 Piața Romana, 1st District, 010371 Bucharest, Romania; nadia.ciocoiu@man.ase.ro (C.N.C.); chitimieaandreea14@stud.ase.ro (A.C.); mminciuu@yahoo.com (M.M.); andreeam.manta@gmail.com (A.-M.M.); eyad247@hotmail.com (I.I.)

2 Department of Business Administration-UNESCO, Bucharest University of Economic Studies, 6 Piața Romana, 1st District, 010371 Bucharest, Romania; simona.vasilache@gmail.com

* Correspondence: cristina.veith@fabiz.ase.ro

check for

updates

Citation: Veith, C.; Vasilache, S.N.; Ciocoiu, C.N.; Chițimiea, A.; Minciu, M.; Manta, A.-M.; Isbaita, I. An Empirical Analysis of the Common Factors Influencing the Sharing and Green Economies. Sustainability 2022, 14, 771. https://doi.org/10.3390/ su14020771

Academic Editor: Stephen Drinkwater

Received: 5 December 2021

Accepted: 6 January 2022

Published: 11 January 2022

Publisher's Note: MDPI stays neutral with regard to jurisdictional claims in published maps and institutional affiliations.

Copyright: (C) 2022 by the authors. Licensee MDPI, Basel, Switzerland. This article is an open access article distributed under the terms and conditions of the Creative Commons Attribution (CC BY) license (https:// creativecommons.org/licenses/by/ $4.0 /)$.

\begin{abstract}
The digital revolution, driven and accelerated by the current pandemic, involves changes to known business models. The innovative model of the sharing economy can be a real and sustainable solution for long-term green economic development. The aim of our research was to determine the common factors of the sharing economy and the green economy and the perceptions of Romanian users regarding them. Our research questionnaire was based on the elements we found in the academic literature. To evaluate the collected data, we used the factor analysis method with the support of the SPSS program. As our study reveals, digitalization as well as inclinations towards saving are factors impacting both the propensity towards sharing and support for the green economy. The demarcation line between the sharing and the green economies is rather fluid, the two realities being under a reciprocal influence. In our model, the green economy develops according to the principles of the sharing economy, going a step further in considering the relationship between society and environment, society and sustainable, eco-friendly behaviour. Although the sharing economy is not necessarily a prerequisite of the green economy, it is, nevertheless, easy for societies or groups that have internalized the lessons of the sharing economy to move forward towards the green economy. This study can be an important tool and a first step for businesses, and, more importantly, for the Romanian public institutions to accelerate the implementation of necessary measures, including legislative ones, in order to promote the further development of these economies.
\end{abstract}

Keywords: sharing economy; green economy; Industry 4.0; sharing market; Romania; drivers

\section{Introduction}

The sharing economy is a relatively new concept which describes a socio-economic model based on the shared use of services and products. This concept has different names in the scientific literature; as well as "the sharing economy", it is known as "the peer-topeer economy", "the mesh economy", "collaborative consumption", "the collaborative economy", "the on-demand economy", "the zero-marginal cost economy" and "crowdbased capitalism". Even if there are certain differences between the definitions of the terms mentioned earlier, these represent in fact only a few examples regarding the general notion of a sharing economy. Being a relatively new concept, in full development and transformation, we do not have a generally accepted definition at this time. The persistently unfavourable general economic situation, characterized by high unemployment rates, low purchasing power, and difficultly in accessing credit, has led the consumer to look for alternatives to save on the purchase of necessary goods and to supplement their personal incomes [1]. The sharing economy has developed due to the difficult general economic situation and the positive pressure in civil society for sustainable development [2]. The 
phenomenon of the sharing economy has seen a significant increase after the economic crisis of 2008 [3].

The appearance of this phenomenon was favoured by the interaction of the following four factors: technological innovations, the global recession, the concept of environmental protection, and, in particular, the emergence of virtual communities. Technological innovations in the area of mobile devices and virtual platforms are the most important factors. The development of digital technologies has stimulated the growth of the sharing economy by ensuring the access of as many participants as possible [1].

The central idea of the sharing economy is not an absolute novelty. The shared use of some goods existed before. The shared use of a good is expressed economically by rent, taxes for a good borrowed or services offered to various groups of people. The big difference today is the global speed and spread of the demand, the supply of shared goods through virtual environments and the fact that bidders are not professional sellers in the context of Industry 4.0. The shared economy is a complex phenomenon that continually reconfigures a diverse spectrum of economic activities. Shared consumption processes can weaken and strengthen conventional business practices. In addition, the sharing economy is also responsible for new forms of inequality and polarization in property relations [4]. Communities in the virtual environment are no longer subject to the classic limitations of space and time. The interest in protecting the environment and the global recession have been factors that favoured the spread of this phenomenon and also the development of the green economy.

With the expansion of this phenomenon, a series of challenges have arisen, both from a legal point of view, as well as from an ethical and moral point of view. These challenges refer mainly to the economic side of this phenomenon. Due to the processes of digitalization and platforming, the sharing economy business models are becoming part of "platform capitalism" with "digital rentiers" causing an unequal distribution of revenues among the sharing economy participants [4]. Taking into account the fact that one of the factors that favoured the development of the sharing economy is the global economic crisis and the resultant need to find solutions to satisfy demands most advantageously, we can understand why the companies of the classical economy are considered at a disadvantage. The sharing economy is mostly found in the field of accommodation and transport (accounting for $80 \%$ of platform investments and $60 \%$ of the total users of this economy) [1]. Whether it is Airbnb or other accommodation booking platforms, the hotel industry is considered disadvantaged. Legal regulations to provide a level playing field for all players in the market are difficult to establish. A similar situation is encountered in the case of transport service providers. The Uber situation is much discussed both from the perspective of taxi companies as well as the majority of traffic participants. For example, Bucharest, which is already very crowded, was filled with cars with out-of-town license plates. In Romania, this phenomenon was not limited to the services area, but it has also experienced an important development in the area of commerce, with used goods and especially with new goods. Platforms like: olx.ro, dressyou.ro, vam-shop.ro, remix.ro, lajumate.ro, autovit.ro, pieseauto.ro, publi24.ro, tripadvisor.com and many others are just a few examples of virtual platforms by means of which you can purchase various goods and services. In the context in which we meet this phenomenon every day, we considered the relevance of an initial search of the scientific literature for a more correct classification of the phenomenon to be followed by a primary analysis of the perception of this phenomenon in the Romanian market.

The pandemic caused by the COVID virus has put the whole world in a completely new situation, socially, politically and economically. This has had special effects on the way many companies are organized and re-evaluated. The digital revolution, driven and accelerated by the current pandemic, involves changing known business models. The innovative model of the sharing economy can be a real and sustainable solution for long-term greener economic development, and in contexts similar to those caused by COVID. Digitalization, from an economic point of view, involves adapting companies to 
new conditions, using modern technologies and creating new business models and new markets. However, this involves the schooling of employees, the company's stakeholders, as well as their customers. These innovative activities and new business models also involve the creation of new forms of job positions [5].

The challenges of moving to a sharing economy to ensure sustainable development, which also ensures the protection of the environment, raise a number of questions, such as: What are the main factors influencing the sharing economy? What are the main factors influencing the green economy? Are there important common factors for the two economic concepts? In this article we try to answer these sorts of questions. The objective of our research was to find and structure the main common factors influencing the sharing and the green economies in our country. To achieve our objective we created a questionnaire and analyzed the perception of an important group of individuals related to the factors influencing the sharing and the green economies. The formulation of the questionnaire was based on elements from the academic literature. We formulated the following hypotheses, which are to be tested in an empirical quantitative analysis. To evaluate the collected data, we used the factor analysis method. The analysis was conducted with the support of the SPSS program.

The research hypotheses are the following:

Hypotheses 1. (H1) The consumer behaviour typical for the sharing economy shapes patterns of behaviour indicative of the green economy as well.

Hypotheses 2. (H2) The inclination towards the sharing economy is influenced by the degree of digitalization.

Hypotheses 3. (H3) The involvement in the sharing economy is influenced by a saving-oriented attitude.

The novelty of the present study is given by the systematic research of the academic literature, but also by the grouping of the multitude of factors influencing the sharing and the green economies in a limited number of components with the help of factor analysis. The grouping of the common factors influencing the two economic concepts brings a clearer picture of the main aspects that influence sustainable development. Another aspect of differentiation refers to the geographical area of this study, namely, Romania. As part of the European Union, Romania shares the same interests regarding a sustainable development of the economy. We need to respect the same rules regarding the regulations of the European Union as all other member states. These rules include those that concern the environment and the objectives for sustainable economic development. As a result of our past as a communist country, older people are focused on owning property. For example, in the European Union, $69.7 \%$ of the population owned a home in 2020 . In Romania, $96.1 \%$ of the population owns a home, the highest percentage in the EU and in the world. The novelty is to perform this study in a country where strong private ownership is prevalent, where "the sharing economy" can have strong connotations of the communist past. Other countries with a high degree of home ownership are Slovakia (92\%), Hungary and Croatia (both with 91\%) [6]. Our results can be taken as inputs for research in countries which show similar patterns of high ownership and a communist past in order to see whether this is an important common element in the relationship with the sharing and green economies. The fact that this study is concentrated on an important group of respondents coming from Romania is also a limitation of the present study. Generations $\mathrm{Y}$ and Z, in general, present a different way of approaching both ownership and work. Generation Y can be said to be more idealistic and Generation $\mathrm{Z}$ much more realistic, being influenced by the difficult periods it has experienced, from the economic crisis to the COVID pandemic [7].

After the general presentation of the subject and the relevance of its study in the current context, we present the main aspects revealed in the academic literature. In Section 3 , we present the method used to collect and evaluate the data obtained, after which we proceeded to present the results. The article concludes by discussing the results, presenting 
the conclusions and limitations of the present research that show the possible areas that can be investigated further.

\section{Literature Review}

\subsection{Conceptual Clarifications of the Sharing Economy}

In the scientific literature, references are made to a wide range of definitions for "the sharing economy". Definitions have been widely discussed and there has been no common agreement, given that this concept is a new one, in full development and of course very controversial. In this paper we will begin by presenting three main definitions formulated between 2015 and 2016. The Oxford Dictionaries introduced the term in 2015 and presented the sharing economy as "an economic system in which assets or services are shared between private individuals, either free or for a fee, typically by means of the Internet" [8]. The definition accepted by the European Commission appears in a report which is the basis of many discussions related to the sharing economy. The definition of the European Commission for this phenomenon is: "commonly used to indicate a wide range of digital commercial or non-profit platforms facilitating exchanges among a variety of players through a variety of interaction modalities (P2P, P2B, B2P, B2B, G2G) that all broadly enable consumption or productive activities leveraging capital assets (money, real estate property, equipment, cars, etc.) goods, skills, or just time" [9]. Benita Matofska and The Sharing People (UK) define the sharing economy as "a socio-economic ecosystem built around the sharing of human and physical resources which includes the shared creation, production, distribution, trade and consumption of goods and services by different people and organizations" [10].

In the book What's Mine Is Yours: The Rise of Collaborative Consumption, Botsman and Rogers make the distinction between the following three terms: "sharing economy", "collaborative economy" and "collaborative consumption" [11]. The sharing economy is described as an economic model based on the redistribution of some underused goods with or without a monetary benefit. This model mainly refers to the relationship between P2P people (person to person) but does not exclude the B2C (business to client) relationship. The collaborative economy is based on distribution platforms by connecting individuals and communities versus using classic organizations. These platforms have the effect of transforming the way we produce, consume, finance and learn. The third term, collaborative consumption, is defined as the economic model based on the sharing, exchange, sale or rental of products and services. Through it, we redefine not only what we consume but also how we consume and our perception of ownership [11]. Botsam and Rogers created a platform for the collaborative economy called collaboriamo.org [11].

The term "mesh" was brought to our attention by Lisa Gansky. This underlined the great potential for economic development on the simple principle of multiplication. She emphasized that connecting any element in a system to any element in any direction within the system, creates possibilities for multiplication [12]. Meshing.it is a platform launched by Gansky which constantly grows in various categories, such as education, energy, travel, entertainment, food, real estate, etc.

"The Peer-to-Peer (P2P) economy" is a term launched by Bauwens in 2006. Dynamics is defined as a process that focuses on the broad growth and spread of participation under equal conditions among interested parties. The idea of this type of economy is that each person realizes what they can offer and each takes what they need. This idea is extended by the author from the economy to society and government. This model, in the author's view, redefines the production and consumption but also the functions of a whole society. To save our planet, Bauwens sees a P2P economy integrated in a P2P society [13].

The concept of a zero marginal cost economy [14] raises the question of continuing the development and existence of the capitalist economy in the form known to us today. Such theories are being fought by various authors; since 2014, Ogden has emphasized that Uber activity itself is only a clear form of capitalism, which uses the latest discoveries for profit [15]. A softer concept, that of crowd-based capitalism [16], discusses the possibility of 
developing classic capitalism in a form that integrates the elements brought by the sharing economy. In support of the ideas presented by Sundararajan comes the work presented by Murillo, who contradicts in his analysis the authors who criticize the sharing economy [17].

This controversial concept is meanwhile regarded as part of the digital economy and not as a new form of economic organization [18]. Another interpretation of the term "sharing economy" treats it as an umbrella, comprising the platform economy, the access economy and the community-based economy [19].

\subsection{Traits of the Sharing Economy}

The different definitions and interpretations of the sharing economy concept are based primarily on the classification differences of the component elements. Acquier, in his work published in 2017, proposes to define the three forms included under the umbrella of "the sharing economy" [19]. The first form is the set of sharing initiatives that optimize the use of underutilized goods (material resources, services or skills) and which is called "the access economy". This aspect we encountered also in other definitions, even though it should be noted that they did not refer to the idea of having access to a good without owning it. One form in which this idea materialized was in that class of companies offering services instead of providing products themselves. The second form, the platform economy, mediates decentralized exchanges through digital platforms in the context of Industry 4.0. These platforms are gaining a share of the market. The community-based economy is the third and perhaps the most complex part of the sharing economy. This refers to coordination initiatives through non-contractual, non-hierarchical or non-monetized forms of interaction. For example, conducting lucrative activities, participating in various projects, or forming exchange relationships are part of the community-based economy. The main purpose of these initiatives is to contribute to the development of communities, to create and strengthen social relations, to protect and promote values and to carry out social projects [19]. If the first two forms are relatively clear, the third one includes the most difficult and debated aspects of the sharing economy, problems related to legality, taxation, etc.

Another interpretation divides the concept of the sharing economy into the following three categories: product redistribution, the shared use of non-material goods and the shared use of material goods [11]. The first form refers to the redistribution of products on platforms such as eBay, where, when a product is no longer wanted or needed, it is offered, at a cost, to others who might want to own it. This type of platform gives the owner the opportunity to either redistribute the goods for free or to recover some of the initial investment by selling the goods or auctioning them. The second form is related to the common use of non-material goods, such as space, time and knowledge. This category includes Landshare, Parkatmy House, Lending Club, Citizen Space initiatives and the Airbnb platform. This form marks, in fact, a major change in lifestyle. The third form refers to the common use of a good and is the form that profoundly changes the concept of ownership [20].

There are three other important aspects of the sharing economy that attract people to it, namely, the ecological, economic and social aspects [21]. By using digital platforms, the client has access to the desired services and products without having to call on intermediaries. This creates an economic advantage for the customer by eliminating commissions and establishing a direct relationship with the provider. There is an economic advantage for the provider, too, as they have access to many more customers and can communicate directly with them in order to improve their offer [22]. The increasing concern for ecology is another important element of the sharing economy. The redistribution of the products completes "the four Rs" (reduce, reuse, recycle and repair). The social aspect refers to the interconnection of a large number of unknown persons who exchange or jointly use goods and services. Communication and exchange with strangers change our lives substantially, giving us the opportunity to trust each other and to collaborate more [20]. An example of cultural exchange is the ERASMUS+ academic program. A general aspect that appears in 
the scientific literature related to the sharing economy is sustainable development in the context of Industry 4.0 [23].

\subsection{Discussions on Legal, Fiscal and Labour Regulations}

The community-based economy component raises various problems and questions related to legal status, the lack of tax regulations and, not least, to labour force regulations [3]. The labour market is the least regulated, and, in the case of Uber, a new form of employee is forecasted, which means no full-time commitment, no entrepreneurial activity. The Uber company does not assume any obligation towards its employees and they do not benefit from any kind of protection [24]. In addition, there is a major power discrepancy between platform owners and users, especially for those who make a living through these tools [25].

Related to the problems resulting from the lack of tax regulations, labour and legal classifications, the main players named are Uber and Airbnb [3]. In Spain, the city of Barcelona took the most drastic attitude against the Airbnb platform, prohibiting owners from renting without prior registration of the activity at the town hall [3].

Depending on which generation we are part of, we are more or less open to what the new forms of economic activity offer us. The most open to these developments are the "Young Millennial" generation. They are more willing to socialize, more open to new experiences and more attentive to the environment [26].

Another point regarding legal regulations concerns the protection of the privacy of each individual. Consumer-to-consumer trading platforms have begun to cross the boundaries between privacy and business. The sale of personal resources (goods, services, knowledge) online is increasingly related to the disclosure of intimate and personal information, endangering privacy security [27].

Trust plays a very important role in all interactions between players in the sharing economy; thus, the technologies that ensure the risk and security of transactions must be adapted to the rapid growth of new economic forms [28]. Regarding trust, another problem that arises is the guarantee of goods and services traded through the sharing economy. This can be solved by integrating the information related to the initial provider guarantees [29].

Regardless of the multitude of problems, struggle between economic interests and societies only brings disadvantages to both parties. The concept of shared value, which focuses on social and economic progress, has the power to bring the next wave of economic growth [30].

\subsection{Green Economy, Sharing Economy and Sustainability}

In many European countries, the current economic model leads to accelerated consumption and extensive use of natural resources. We are increasingly noticing that this model is becoming more vulnerable to developments in global markets. People have a positive attitude towards green products. More and more people are looking for organic products, which is very important for the transition to a green economy. This interest is closely linked to the level of knowledge about green products [31].

The green economy has a beneficial effect on increasing human well-being and social equality. It reduces environmental threats and improves the use of natural resources. Many countries are concerned with finding solutions to ensure the protection of the environment and conservation of limited natural resources. According to Sulich, there are two main groups of factors that support the development of the green economy. These factors are innovation and corporate social responsibility [32].

The European strategy emphasizes the opportunities offered by the green economy. The EU project for the "3Ps" (people, planet and profit) refers to the combination of decent work, job satisfaction and environmental protection. One of the sectors of activity that has suffered and is suffering as a result of the COVID pandemic is tourism. The green economy and the EU's promotion programs in this direction represent great opportunities for the tourism sector. From a strategic point of view, it is a good opportunity to design a green recovery for this sector. This may also include the transformation of tourism jobs into 
green jobs. In general, this approach can be an example for other sectors and for ensuring sustainable investment in a better future [33].

In the age of globalization, researchers, economists, various types of national and international organizations and governmental and non-governmental organizations are concerned with how to improve production processes, reduce air emissions and solid waste through innovative green technologies. In general, management should place more emphasis on sustainable development and environmental protection by promoting best practices and raising social awareness of environmental issues [34]. Sustainability and sustainable development are on the agenda of most governments and civil servants. The introduction of measures to encourage the development of business models based on the sharing of goods and services, as well as legal regulations that reduce certain obstacles to their development, can help to achieve the goals of sustainable development [35].

In order to be able to protect the environment and ensure economic growth with lower emissions, less property ownership appears as a key factor. This implies a new culture of consumption, in which ownership of products is not the main goal. The main objective may be to ensure access to the functionalities that the property brings today. It has been suggested that leasing rather than ownership is the cornerstone of the business model that ensures real environmental protection [36].

In a broad understanding, the sharing economy refers to business models that aim to provide convenient and cost-effective access to underused or redundant resources facilitated by digital platforms. The sharing economy can facilitate the restructuring of the classical economy towards more sustainable business and consumption models. In some cases, the sharing economy can be a means to reach a green economy by using resources more efficiently and reducing the need to buy more physical goods, reducing the transport of physical goods in order to shorten distances and raising awareness of the need for environmental protection by providing more sustainable consumption patterns [37].

The sharing economy is closely tied to the green economy, linked to sustainability, and defined in terms of (a) an economic opportunity, (b) a more sustainable form of consumption and (c) a path to a fair and sustainable economy. The sharing economy is an opportunity for sustainability [38]. The ability to use goods without having to own them reduces the need to produce more goods and reduces waste. In order to really ensure a rapprochement with the green economy, we must also refer to the producers of goods. For companies, the sharing economy can be an opportunity and it is recommended that they implement environmental corporate social responsibility that influences users' perceptions of sustainability and allows the creation of a brand [38].

Karobliene and Pilinkiene present a conceptual model of the impact of the sharing economy on the sustainable development of countries, based on the following factors: decent work and economic growth; industry, innovation and infrastructure; reducing inequalities; responsible consumption and production; business development factors; technology (use of ICT) and innovation. This model makes a link between the sharing economy and sustainable development. It also states that the shared economy offers an opportunity to strengthen economic and digital development in small countries [39].

Technological innovation, as well as institutional innovation, can significantly influence the growth of the green economy [40].

Digitalization is a contributing factor to the transition to a circular economy. Today's technologies, such as artificial intelligence, the Internet of Things, big data and blockchain, are the "facilitators" of various production processes that improve the use of natural resources and optimize the design, production, repair and recycling of certain products. Digitalization alone will not automatically lead to higher principles of sustainability. Policy tools and strategies are needed to drive digitalization and innovation and manage complex sustainability issues [41].

The main role of ICT is to apply a push and save impact in order to optimize the economic processes of production, consumption and circulation in the use hierarchies of the resources that underlie all products [42]. 
Management is looking at the potential of Industry 4.0 smart technologies in order to create a better economy, including a greener economy. The European Commission aims to deliver the European Green Pact by rethinking clean energy policies. Industry 4.0 will eventually apply to all aspects of life. That is why it is necessary to identify the challenges for the adoption of Industry 4.0 for a sustainable digital transformation [43].

Concerns about digitalization, the green economy and the links between these revolutionary models are not only to be found at the EU level. Even in Russia, there is a concern at the state level to support investments in environmental protection. A system of state support measures for environmental investments is being formed in Russia. These measures can also be co-financed by the state together with large companies [44].

In the case of Romania, EU programs for the development of a green economy, including those for agriculture, have been received with great interest. Thus, Romania could have an agricultural sector with well-paid employees, with training programs for managers and employees and more investments in multidimensional networks [45].

Recycling is a key factor in the development of a green economy and the possibilities of expanding recycling systems, including those for carbon dioxide, as an essential chemical, are being explored. When there are cheap, high-purity $\mathrm{CO}_{2}$ capture techniques and economical techniques to transform it, significant carbon savings will be achieved. Carbon dioxide can be used as a raw material to produce urea, salicylic acid and plastics that have already been commonly produced. Supercritical carbon dioxide also has many applications in food, chemicals and micro-pharmaceuticals [46]. In many areas globally, there are concerns about transforming the classical economy into a slightly greener economy.

\section{Materials and Methods}

\subsection{Selection of Methods}

This paper includes a secondary analysis, based on the study of already published materials, with the purpose of framing and understanding the phenomenon of the sharing and green economies. The analysed documentation has been found in various publications and scientific articles in recent years. The comprehensive search took into consideration numerous sources of secondary data, such as articles, reports and books from the domains "sharing economy", "green economy", "Industry 4.0", environment protection and "sharing market". Electronic databases, such as us Springer, Academia.edu, BRILL, MDPI (mainly Sustainability), Sage, Palgrave and Wiley Online Library were also used. The data sources studied present these two global phenomena and only a small part of them make references to the situation in Romania.

The first method used is, therefore, a descriptive one, given the fact that the subject is very wildly and controversially discussed. The second method used was a quantitative empirical analysis. Taking into account the real possibilities at the moment, both for data collection and for keeping costs within a normal limit, we chose to use a questionnaire. For data processing we took into account the large number of influencing factors for the green and sharing economies and we chose factor analysis. This tool is used when the number of factors is large, as in the area under discussion, allowing us to group them into components. The program used to evaluate the data was SPSS.

The use of factor analysis gives us a result which is easy to analyse, the tool transforming numerical data tables, generated through descriptive statistical analysis, into graphs that are easy to read. The resultant components enabled us to understand which are the main aspects through which people are influenced to participate in the sharing and green economies. When the number of factors is too large, the complexity of the situation makes it difficult to identify the way in which different factors correlate with each other. Hair defined factor analysis as "an interdependence technique whose primary purpose is to define the underlying structure among the variables in the analysis" [47].

Factor analysis is used to solve three types of problems: reducing the number of variables to increase the speed of data processing and identifying hidden patterns in the relationships between data, underlying dimensions or factors that explain the correlations 
among a set of variables; to identify a new, smaller set of uncorrelated variables to replace the original set of correlated variables in subsequent multivariate analysis; and to identify a smaller set of salient variables from a larger set for use in subsequent multivariate analysis. Factor analysis refers to a wide range of statistical techniques used to represent a set of variables in accordance with a small number of hypothetical variables called "factors" [48].

This type of analysis is used extensively in various fields, such as psychology, the social sciences, production management, operational research, development, etc. Some of the software packages dedicated to this type of analysis are Statistics, SAS and SPSS [49].

\subsection{Data Collection and Preparation}

In this article, we tried, as a first step, to identify on the basis of the academic literature the main influencing factors in the sharing and green economies. Based on the information obtained, we proceeded to formulate the questions for the online questionnaire, which was offered to the target groups of respondents.

Each questionnaire included eight questions regarding the sharing and green economies and consisted of three main parts, as presented in Appendix A. The first part referred to the clarification of the factors influencing involvement in the "sharing economy". In this first part, we presented 24 different factors that influence participation in the sharing economy and which are partially common to those of the green economy. The respondents had to choose how much each factor influences their willingness to participate in the sharing economy on a Likert scale from 1 to 7 . The second part of the questionnaire included the next three questions and the respondents had to evaluate the possible relationship between the green economy and the sharing economy and the possibility of protecting the environment by sharing goods. The third part of the questionnaire included four questions regarding crowdsourcing. The four questions in the third part, like all the other main questions in the questionnaire, were closed questions; the respondents had to choose their answer on a Likert scale from 1 to 7 ( $1=$ total disagreement and $7=$ total agreement $)$. In the last part of the questionnaire, the respondents had six classification questions regarding age, income, gender, education, professional status and origin (urban or rural). At the beginning of the questionnaire we presented the definition of the green and sharing economies and the term "crowdsourcing". The time needed to complete the questionnaire varied between 5 and $10 \mathrm{~min}$. The research was conducted in accordance with the questionnaire rules and respected the anonymity of the interviewed persons. Conducting the research was a complex and laborious activity, mainly because the timeframe was very tight and the respondents had to be selected properly in order to answer carefully all the questions.

The answers were carefully analysed, divided into categories and systematically compared using factor analysis. After a series of trials, we decided to take all the answers in one big group and not split them up by the different classification variables. This approach was used to get a maximum of information from the collected data and to identify the main concepts and common elements for all respondents [50]. The resulting four components were compared with those found in the academic literature. These refer to economic benefits, efficiency, lack of confidence, sustainability, environmental protection and community [51]. The four components derived from the study were: economic and ecological benefits, digitalization, the green economy and environment protection.

The results obtained from the questionnaire were analysed using the factor analysis method, evaluated with the support of the SPSS program. The questionnaire was completed online and the respondents had 60 days, between September and November 2021, to answer the closed questions formulated in order to validate the proposed hypothesis.

The questionnaire was distributed mainly among young people from Bucharest, Brasov and Ploiesti, being available online also to other people who had experiences in the area of the green and sharing economies.

Our questionnaire was answered by 568 people, mostly young ones. Only 553 answers were taken into consideration in the final analysis because of some missing answers. This number was more than enough because the rule of thumb for sample size in factor analysis 
tells us that we need to have at least five times as many cases as variables entered in the analysis plus 10 [48]. Knowing from the literature that the people with the most advanced skills in the area of digital media are mainly young people aged between 18 and 35 , they were the main target of our questionnaire and we received 441 answers from this group [52]. Another age segment willing to use digital platforms are people between 18 and 45 years old $[53,54]$. From this enlarged group we received 511 answers. Regarding gender, it was observed that there were no representative differences in the use of digital platforms in the age segment between women and men [55]. Differences occur in the use and frequency of use of digital platforms, according to the traditional cultural roles of women and men [56]. Other elements that differentiate openness and the effective use of digital platforms, including those of the sharing economy type, are level of education, income, urban background and ethnic and cultural differences [57]. The level of education and acquired digital skills are important variables in using and being active on digital platforms, including those of the sharing economy $[21,58]$.

Students represent perhaps the most important segment of users of digital platforms, given their inclusion both in the age group and in the training and education segment with the highest level of use. Although seemingly paradoxical, the use of sharing economy platforms is more widespread among people with higher incomes [55]. Active participation in the sharing economy area is higher for relatively young people with at least a mediumto-high level of education and a good income. These people come mainly from urban areas, where access to the Internet and technology is much more advanced than in many rural areas. Car-sharing services are used much more by people in urban areas, who by default have to travel longer distances on a regular basis. Urban agglomeration makes many choose this type of service instead of traveling using their own vehicle. It was found that the principle of car-sharing has been successfully embraced in Europe by companies that have managed to grow and respect the goals of sustainable development [2]. For owners of digital platforms, especially those who offer products and services for profit, urban agglomerations are more interesting because the number of potential customers is higher [57]. Another aspect for which urban agglomerations are preferred is the possibility of sustainable virtual networks.

The degree of participation in the sharing economy also depends on the cultural specificity of a certain country and/or belonging to a certain ethnic minority. In Germany, the idea of sharing is common in relation to driving or shared housing, especially for the first home when young people leave their parents' homes. In Britain, the desire and willingness to share property with other owners is much lower than in other countries. In France, the number of people willing to participate in the sharing economy is much higher. Italians associate the idea of the sharing economy with an answer to an economic crisis, a convenience, an innovative idea, a different kind of barter, a method of environmental protection, a modern and ethical solution, as well as offering ways to get to know other people [59].

In Switzerland, the German-speaking population is less willing and open to use the products and services of the sharing economy [58]. In conclusion, we can say that the reasons for active participation in the sharing economy depend on different sociodemographic aspects and cultural and ethnic values. Internet access is divided in the literature into two categories, namely, physical access and motivational access [60]. The differences in internet access depend on the unequal distribution of resources (in time and space, in a culture, society or economy). These are related to age, gender, digital skills, personality and position in society. Motivational access to the Internet is determined and influenced in general by an individual's perception of the opportunities offered by its use, lack of time, lack of personal experience in the field, a negative attitude towards the virtual environment, fear of the unknown or lack of skills. In Western culture, the non-use of the Internet is linked to an unfavourable attitude towards modern technology in the ICT industry. These people generally gain the benefits of the Internet by relying on other family members, friends or acquaintances, without acknowledging its indirect use [57]. Regarding 
the general use of new technologies, there is an inequality between users due to several main factors, such as the necessary material resources, digital knowledge and skills and effective access to the Internet.

In the area of the sharing and green economies we encounter other elements of inequality between participants. These generally refer to the results of the reviews of the various participants. Special access to information and the comments posted on digital platforms offer the customer the opportunity to choose the desired product or service not only from the perspective of technical specifications, cost and services offered, but also from the perspective of choosing the desired bidder [19]. Out of the total of 568 responses received to our questionnaire, only 553 were validated and taken into account in the analysis conducted with the support of the SPSS program. Of these, 312 were women and 241 were men; 151 came from rural areas and 402 from urban areas; 196 were undergraduates and 357 had graduated; 298 were students, 189 were employees and 66 were managers. Our questionnaire was not answered by people without commitments or not engaged in a professional activity. A majority represented people with incomes above the national average.

\section{Results}

In our factor analysis, we considered 31 variables, 24 from the first part of the questionnaire, three from the second part and four from the fourth part. These variables are presented in Table 1. According to the rules of the chosen analysis, the variables were measured with a Likert scale from 1 to 7.

The collected data from the questionnaire were exported from Google Forms to an Excel document, which we translated into English and prepared for upload to SPSS. After choosing factor analysis, we selected coefficients and the correlation matrix. The matrix summarizes the interrelationship among the set of selected variables or items on a scale. If the correlation among the selected items was inadequate, then we knew that our factor analysis would be irrelevant. The determinant of the correlation matrix takes values between 0.00 and 1.00. We needed to test that our variables were correlated and if all off-diagonal elements equal 0.00 then the variables are not correlated. According to the results in Table 2, all results took values other than 0.00. A higher absolute value in the correlation matrix indicates a stronger relationship between two variables. When the value was positive, then we knew that a direct relationship between two items existed. In Table 2, we can see that between a lot of variables show a very strong correlation. For example, the correlation between the first five variables is very strong. The result of the correlation presented in Table 2 tells us that our decision to apply factor analysis was correct and that the hypothesized factor model appears to be appropriate. The determinant for our variables is greater than the cut-off value of 0.00001 . Therefore, we can say that the correlation matrix is good enough; there are sufficient interrelationships among the studied variables.

The reason for using principal component analysis was to summarize the interrelationships among variables in terms of a smaller set of orthogonal components that are linear combinations of the original variables.

In the next step, we wanted to find out how much of the total variance could be explained by a small group of components. We therefore analysed the Eigenvalues, this method being recommended for studies with between 20 and 50 variables [48].

Table 4 presents the communality of the main four components that we took into consideration. These four factors account for $45.641,7.378,6.013$ and $4.283 \%$ of the total variance, respectively. This means a total of more than $63 \%$ of the total variance is attributable to these four components. The remaining 27 variables/components together account for only approximately $36.7 \%$ of the variance. Thus, a model with four factors may be adequate to represent the data. 
Table 1. List of Variables for the factor analysis.

\begin{tabular}{|c|c|}
\hline Nr. & Variables $($ Likert-Scale $1=$ Not at All $/ \ldots / 7=$ Totally) \\
\hline 1 & Internet access. \\
\hline 2 & Digital skills. \\
\hline 3 & Digital platforms. \\
\hline 4 & Comfort on digital platforms. \\
\hline 5 & Comparing offers on digital platforms. \\
\hline 6 & Varied offer of products and services on digital platforms. \\
\hline 7 & Easy access to information from around the world for products and services. \\
\hline 8 & Lower costs through more direct buyer-seller contact. \\
\hline 9 & Access to goods without ownership. \\
\hline 10 & Access to second-hand goods at lower costs. \\
\hline 11 & Possibility of protecting the environment by purchasing goods with a certain wear. \\
\hline 12 & Possibility of sharing goods to reduce resource consumption. \\
\hline 13 & Possibility of recovering part of the investment by selling a good with a certain wear and tear. \\
\hline 14 & Possibility of sharing a good to reduce the financial effort related to its exclusive possession. \\
\hline 15 & Possibility of recovering part of the investment by renting or lending an asset. \\
\hline 16 & Possibility of capitalizing on excess owned resources. \\
\hline 17 & Sharing to increase resource efficiency. \\
\hline 18 & Sharing spaces for professional activity. \\
\hline 19 & Common use of electric scooters. \\
\hline 20 & Decreasing consumption through the shared use of goods. \\
\hline 21 & Reducing losses/costs through the shared use of goods. \\
\hline 22 & Car-sharing to protect the environment. \\
\hline 23 & The need to reduce waste and the sharing economy. \\
\hline 24 & Environment—care and the sharing economy. \\
\hline 25 & Development of the green economy through the sharing economy. \\
\hline 26 & Postpone the purchase of your own car for at least a year because of access to car-sharing. \\
\hline 27 & The possibility of benefitting from car-sharing persuaded you to give up your personal car. \\
\hline 28 & Crowdsourcing can support the development of a greener economy. \\
\hline 29 & An application, such as Waze, can reduce traffic congestion and thus reduce pollution. \\
\hline 30 & The support of crowdsourcing for the realization of smart projects that reduce pollution. \\
\hline 31 & The design for smart homes that offer a greener way of life can be achieved with crowdsourcing. \\
\hline
\end{tabular}


Table 2. Correlation Matrix.

\begin{tabular}{|c|c|c|c|c|c|c|c|c|c|c|c|c|c|c|c|c|c|c|c|c|c|c|c|c|c|c|c|c|c|c|c|}
\hline & 1 & 2 & 3 & 4 & 5 & 6 & 7 & 8 & 9 & 10 & 11 & 12 & 13 & 14 & 15 & 16 & 17 & 18 & 19 & 20 & 21 & 22 & 23 & 24 & 25 & 26 & 27 & 28 & 29 & 30 & 31 \\
\hline 1 & 1.000 & 0.613 & 0.579 & 0.623 & 0.604 & 0.602 & 0.604 & 0.564 & 0.383 & 0.415 & 0.402 & 0.343 & 0.419 & 0.396 & 0.435 & 0.397 & 0.451 & 0.416 & 0.255 & 0.324 & 0.395 & 0.346 & 0.434 & 0.375 & 0.290 & 0.142 & 0.141 & 0.268 & 0.245 & 0.270 & 0.291 \\
\hline 2 & 0.613 & 1.000 & 0.679 & 0.622 & 0.547 & 0.550 & 0.511 & 0.532 & 0.425 & 0.464 & 0.467 & 0.431 & 0.392 & 0.461 & 0.436 & 0.410 & 0.471 & 0.452 & 0.391 & 0.444 & 0.434 & 0.380 & 0.431 & 0.426 & 0.336 & 0.138 & 0.177 & 0.328 & 0.275 & 0.288 & 0.313 \\
\hline 3 & 0.579 & 0.679 & 1.000 & 0.714 & 0.612 & 0.606 & 0.543 & 0.584 & 0.451 & 0.495 & 0.471 & 0.473 & 0.485 & 0.556 & 0.524 & 0.479 & 0.497 & 0.465 & 0.382 & 0.484 & 0.492 & 0.443 & 0.453 & 0.411 & 0.334 & $\begin{array}{l}0.222 \\
\end{array}$ & 0.266 & 0.318 & 0.248 & 0.349 & 0.326 \\
\hline 4 & 0.623 & 0.622 & 0.714 & 1.000 & 0.657 & 0.647 & 0.626 & 0.656 & 0.543 & 0.543 & 0.480 & 0.491 & 0.488 & 0.554 & 0.563 & 0.507 & 0.475 & 0.462 & 0.406 & 0.468 & 0.495 & 0.471 & 0.499 & 0.465 & 0.345 & 0.205 & 0.243 & 0.317 & 0.273 & 0.332 & 0.347 \\
\hline 5 & 0.604 & 0.547 & 0.612 & 0.657 & 1.000 & 0.749 & 0.635 & 0.628 & 0.457 & 0.517 & 0.466 & 0.409 & 0.480 & 0.482 & 0.536 & 0.496 & 0.485 & 0.436 & 0.330 & 0.394 & 0.410 & 0.417 & 0.469 & 0.404 & 0.358 & 0.199 & 0.202 & 0.317 & 0.293 & 0.312 & 0.325 \\
\hline 6 & 0.602 & 0.550 & 0.606 & 0.647 & 0.749 & 1.000 & 0.663 & 0.649 & 0.440 & 0.470 & 0.455 & 0.408 & 0.478 & 0.505 & 0.549 & 0.547 & 0.519 & 0.441 & 0.325 & 0.415 & 0.447 & 0.417 & 0.504 & 0.454 & 0.293 & 0.157 & 0.210 & 0.289 & 0.272 & 0.337 & 0.312 \\
\hline 7 & 0.604 & 0.511 & 0.543 & 0.626 & 0.635 & 0.663 & 1.000 & 0.600 & 0.451 & 0.417 & 0.426 & 0.395 & 0.423 & 0.446 & 0.505 & 0.381 & 0.404 & 0.406 & 0.277 & 0.311 & 0.333 & 0.392 & 0.468 & 0.465 & 0.274 & 0.212 & 0.188 & 0.210 & 0.251 & 0.255 & 0.295 \\
\hline 8 & 0.564 & 0.532 & 0.584 & 0.656 & 0.628 & 0.649 & 0.600 & 1.000 & 0.539 & 0.556 & 0.500 & 0.489 & 0.542 & 0.552 & 0.573 & 0.561 & 0.505 & 0.473 & 0.369 & 0.445 & 0.515 & 0.424 & 0.509 & 0.439 & 0.331 & 0.193 & 0.270 & 0.302 & 0.293 & 0.324 & 0.314 \\
\hline 9 & 0.383 & 0.425 & 0.451 & 0.543 & 0.457 & 0.440 & 0.451 & 0.539 & 1.000 & 0.653 & 0.613 & 0.561 & 0.543 & 0.601 & 0.591 & 0.545 & 0.538 & 0.524 & 0.421 & 0.515 & 0.557 & 0.487 & 0.447 & 0.390 & 0.350 & 0.310 & 0.351 & 0.305 & 0.277 & 0.328 & 0.405 \\
\hline 10 & 0.415 & 0.464 & 0.495 & 0.543 & 0.517 & 0.470 & 0.417 & 0.556 & 0.653 & 1.000 & 0.663 & 0.560 & 0.577 & 0.610 & 0.594 & 0.568 & 0.559 & 0.507 & 0.421 & 0.514 & 0.555 & 0.432 & 0.452 & 0.353 & 0.375 & 0.213 & 0.299 & 0.337 & 0.255 & 0.314 & 0.370 \\
\hline 11 & 0.402 & 0.467 & 0.471 & 0.480 & 0.466 & 0.455 & 0.426 & 0.500 & 0.613 & 0.663 & 1.000 & 0.697 & 0.588 & 0.580 & 0.532 & 0.564 & 0.508 & 0.464 & 0.433 & 0.529 & 0.533 & 0.539 & 0.577 & 0.533 & 0.375 & 0.241 & 0.263 & 0.327 & 0.299 & 0.332 & 0.391 \\
\hline 12 & 0.343 & 0.431 & 0.473 & 0.491 & 0.409 & 0.408 & 0.395 & 0.489 & 0.561 & 0.560 & 0.697 & 1.000 & 0.586 & 0.701 & 0.547 & 0.575 & 0.597 & 0.488 & 0.446 & 0.613 & 0.569 & 0.558 & 0.564 & 0.524 & 0.334 & 0.266 & 0.314 & 0.342 & 0.328 & 0.361 & 0.378 \\
\hline 13 & 0.419 & 0.392 & 0.485 & 0.488 & 0.480 & 0.478 & 0.423 & 0.542 & 0.543 & 0.577 & 0.588 & 0.586 & 1.000 & 0.576 & 0.643 & 0.663 & 0.521 & 0.448 & 0.354 & 0.455 & 0.490 & 0.456 & 0.484 & 0.440 & 0.334 & 0.191 & 0.240 & 0.333 & 0.316 & 0.376 & 0.397 \\
\hline 14 & 0.396 & 0.461 & 0.556 & 0.554 & 0.482 & 0.505 & 0.446 & 0.552 & 0.601 & 0.610 & 0.580 & 0.701 & 0.576 & 1.000 & 0.680 & 0.630 & 0.665 & 0.590 & 0.507 & 0.642 & 0.616 & 0.556 & 0.527 & 0.462 & 0.369 & 0.276 & 0.343 & 0.343 & 0.292 & 0.356 & 0.430 \\
\hline 15 & 0.435 & 0.436 & 0.524 & 0.563 & 0.536 & 0.549 & 0.505 & 0.573 & 0.591 & 0.594 & 0.532 & 0.547 & 0.643 & 0.680 & 1.000 & 0.635 & 0.613 & 0.517 & 0.395 & 0.523 & 0.547 & 0.513 & 0.518 & 0.465 & 0.381 & 0.268 & 0.299 & 0.351 & 0.307 & 0.380 & 0.447 \\
\hline 16 & 0.397 & 0.410 & 0.479 & 0.507 & 0.496 & 0.547 & 0.381 & 0.561 & 0.545 & 0.568 & 0.564 & 0.575 & 0.663 & 0.630 & 0.635 & 1.000 & 0.685 & 0.547 & 0.434 & 0.568 & 0.567 & 0.487 & 0.515 & 0.455 & 0.346 & 0.201 & 0.313 & 0.316 & 0.275 & 0.379 & 0.426 \\
\hline 17 & 0.451 & 0.471 & 0.497 & 0.475 & 0.485 & 0.519 & 0.404 & 0.505 & 0.538 & 0.559 & 0.508 & 0.597 & 0.521 & 0.665 & 0.613 & 0.685 & 1.000 & 0.634 & 0.489 & 0.638 & 0.636 & 0.486 & 0.468 & 0.403 & 0.363 & 0.187 & 0.303 & 0.333 & 0.284 & 0.351 & 0.413 \\
\hline 18 & 0.416 & 0.452 & 0.465 & 0.462 & 0.436 & 0.441 & 0.406 & 0.473 & 0.524 & 0.507 & 0.464 & 0.488 & 0.448 & 0.590 & 0.517 & 0.547 & 0.634 & 1.000 & 0.554 & 0.587 & 0.588 & 0.489 & 0.430 & 0.426 & 0.301 & 0.175 & 0.282 & 0.270 & 0.197 & 0.281 & 0.336 \\
\hline 19 & 0.255 & 0.391 & 0.382 & 0.406 & 0.330 & 0.325 & 0.277 & 0.369 & 0.421 & 0.421 & 0.433 & 0.446 & 0.354 & 0.507 & 0.395 & 0.434 & 0.489 & 0.554 & 1.000 & 0.662 & 0.570 & 0.551 & 0.392 & 0.392 & 0.272 & 0.270 & 0.310 & 0.249 & 0.193 & 0.222 & 0.230 \\
\hline 21 & 0.395 & 0.434 & 0.492 & 0.495 & 0.410 & 0.447 & 0.333 & 0.515 & 0.557 & 0.555 & 0.533 & 0.569 & 0.490 & 0.616 & 0.547 & 0.567 & 0.636 & 0.588 & 0.570 & 0.781 & 1.000 & 0.539 & 0.502 & 0.464 & 0.390 & 0.187 & 0.234 & 0.324 & 0.252 & 0.323 & 0.330 \\
\hline 22 & 0.346 & 0.380 & 0.443 & 0.471 & 0.417 & 0.417 & 0.392 & 0.424 & 0.487 & 0.432 & 0.539 & 0.558 & 0.456 & 0.556 & 0.513 & 0.487 & 0.486 & 0.489 & 0.551 & 0.587 & 0.539 & 1.000 & 0.612 & 0.560 & 0.379 & 0.395 & 0.402 & 0.365 & 0.297 & 0.348 & 0.392 \\
\hline 23 & 0.434 & 0.431 & 0.453 & 0.499 & 0.469 & 0.504 & 0.468 & 0.509 & 0.447 & 0.452 & 0.577 & 0.564 & 0.484 & 0.527 & 0.518 & 0.515 & 0.468 & 0.430 & 0.392 & 0.486 & 0.502 & 0.612 & 1.000 & 0.752 & 0.404 & 0.226 & 0.204 & 0.322 & 0.294 & 0.362 & 0.337 \\
\hline 24 & 0.375 & 0.426 & 0.411 & 0.465 & 0.404 & 0.454 & 0.465 & 0.439 & 0.390 & 0.353 & 0.533 & 0.524 & 0.440 & 0.462 & 0.465 & 0.455 & 0.403 & 0.426 & 0.392 & 0.481 & 0.464 & 0.560 & 0.752 & 1.000 & 0.397 & 0.198 & 0.168 & 0.307 & 0.294 & 0.336 & 0.294 \\
\hline 25 & 0.290 & 0.336 & 0.334 & 0.345 & 0.358 & 0.293 & 0.274 & 0.331 & 0.350 & 0.375 & 0.375 & 0.334 & 0.334 & 0.369 & 0.381 & 0.346 & 0.363 & 0.301 & 0.272 & 0.377 & 0.390 & 0.379 & 0.404 & 0.397 & 1.000 & 0.278 & 0.242 & 0.511 & 0.410 & 0.502 & 0.467 \\
\hline 26 & 0.142 & 0.138 & 0.222 & 0.205 & 0.199 & 0.157 & 0.212 & 0.193 & 0.310 & 0.213 & 0.241 & 0.266 & 0.191 & 0.276 & 0.268 & 0.201 & 0.187 & 0.175 & 0.270 & 0.231 & 0.187 & 0.395 & 0.226 & 0.198 & 0.278 & 1.000 & 0.690 & 0.301 & 0.240 & 0.269 & 0.307 \\
\hline 27 & 0.141 & 0.177 & 0.266 & 0.243 & 0.202 & 0.210 & 0.188 & 0.270 & 0.351 & 0.299 & 0.263 & 0.314 & 0.240 & 0.343 & 0.299 & 0.313 & 0.303 & 0.282 & 0.310 & 0.305 & 0.234 & 0.402 & 0.204 & 0.168 & 0.242 & 0.690 & 1.000 & 0.341 & 0.234 & 0.287 & 0.346 \\
\hline 28 & 0.268 & 0.328 & 0.318 & 0.317 & 0.317 & 0.289 & 0.210 & 0.302 & 0.305 & 0.337 & 0.327 & 0.342 & 0.333 & 0.343 & 0.351 & 0.316 & 0.333 & 0.270 & 0.249 & 0.368 & 0.324 & 0.365 & 0.322 & 0.307 & 0.511 & 0.301 & 0.341 & 1.000 & 0.525 & 0.667 & 0.596 \\
\hline 29 & 0.245 & 0.275 & 0.248 & 0.273 & 0.293 & 0.272 & 0.251 & 0.293 & 0.277 & 0.255 & 0.299 & 0.328 & 0.316 & 0.292 & 0.307 & 0.275 & 0.284 & 0.197 & 0.193 & 0.291 & 0.252 & 0.297 & 0.294 & 0.294 & 0.410 & 0.240 & 0.234 & 0.525 & 1.000 & 0.600 & 0.485 \\
\hline 30 & 0.270 & 0.288 & 0.349 & 0.332 & 0.312 & 0.337 & 0.255 & 0.324 & 0.328 & 0.314 & 0.332 & 0.361 & 0.376 & 0.356 & 0.380 & 0.379 & 0.351 & 0.281 & 0.222 & 0.342 & 0.323 & 0.348 & 0.362 & 0.336 & 0.502 & 0.269 & 0.287 & 0.667 & 0.600 & 1.000 & 0.674 \\
\hline 31 & 0.291 & 0.313 & 0.326 & 0.347 & 0.325 & 0.312 & 0.295 & 0.314 & 0.405 & 0.370 & 0.391 & 0.378 & 0.397 & 0.430 & 0.447 & 0.426 & 0.413 & 0.336 & 0.230 & 0.379 & 0.330 & 0.392 & 0.337 & 0.294 & 0.467 & 0.307 & 0.346 & 0.596 & 0.485 & 0.674 & 1.000 \\
\hline
\end{tabular}

Source: Made by the authors in SPSS.The Kaiser-Meyer-Olkin test (Table 3), or the KMO test for short, helped us to verify if our sampling was adequate. Our result of 0.956 told us that our sampling adequacy was very good indeed. Sampling is acceptable if the result of the KMO test is greater than 0.6. The statistical null hypothesis, which says that the correlation matrix is an identity matrix, could therefore be rejected. Bartlett's test confirmed the result of rejecting the null hypothesis-that there are good interrelationships between the study

items and measures. 
Table 3. KMO and Bartlett's Tests.

\begin{tabular}{llc}
\hline \multicolumn{2}{c}{ Kaiser-Meyer-Olkin Measure of Sampling Adequacy } & 0.956 \\
\hline \multirow{3}{*}{ Bartlett's Test of Sphericity } & Approx. Chi-Square & $12,060.265$ \\
\cline { 2 - 3 } & $\mathrm{df}$ & 465 \\
\cline { 2 - 3 } & Sig. & 0.000 \\
\hline
\end{tabular}

Source: Made by the authors in SPSS

Table 4. Total Variance Explained-the four components.

\begin{tabular}{|c|c|c|c|c|c|c|c|c|c|}
\hline \multirow[b]{2}{*}{ Component } & \multicolumn{3}{|c|}{ Initial Eigenvalues } & \multicolumn{3}{|c|}{ Extraction Sums of Squared Loadings } & \multicolumn{3}{|c|}{ Rotation Sums of Squared Loadings } \\
\hline & Total & $\begin{array}{c}\% \text { of } \\
\text { Variance }\end{array}$ & Cumulative \% & Total & $\begin{array}{c}\% \text { of } \\
\text { Variance }\end{array}$ & Cumulative \% & Total & $\begin{array}{c}\% \text { of } \\
\text { Variance }\end{array}$ & Cumulative \% \\
\hline 1 & 14.149 & 45.641 & 45.641 & 14.149 & 45.641 & 45.641 & 8.075 & 26.048 & 26.048 \\
\hline 2 & 2.287 & 7.378 & 53.019 & 2.287 & 7.378 & 53.019 & 5.990 & 19.321 & 45.369 \\
\hline 3 & 1.864 & 6.013 & 59.032 & 1.864 & 6.013 & 59.032 & 3.688 & 11.897 & 57.266 \\
\hline 4 & 1.328 & 4.283 & 63.316 & 1.328 & 4.283 & 63.316 & 1.875 & 6.050 & 63.316 \\
\hline
\end{tabular}

Source: Made by the authors in SPSS.

Unrotated factor solutions achieve the objective of data reduction but they cannot provide enough information for the most adequate interpretation of the variables under examination. The solution here was to find the best rotation method for achieving better factor solutions. When we are analysing Figure 1 with the Scree Plot, we can clearly see that the most important component is the first one. According to the factors included, we named the first component "economic and ecological benefits". The next component is digitalisation, followed by factors common to the green and sharing economies. The last component was named "environmental protection", even though this subject can also be found in other factors among the components.

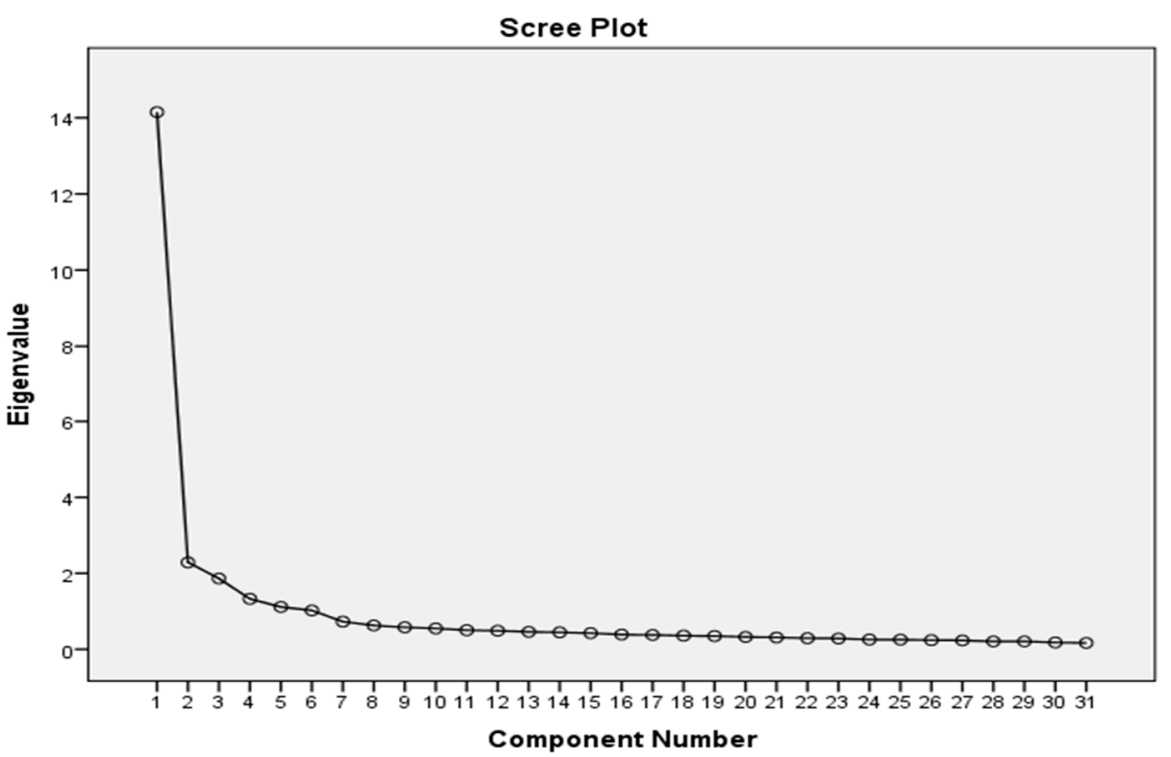

Figure 1. The scree plot of the components for the 31 variables of the factor analysis. Source: made by the authors in SPSS.

Table 5 shows the component matrix with the rotated factors. The loading of the factors forming the four components is greater than 0.50. Actually, every component has some loading from every variable but there are blanks in the matrix where weights were less than 0.50 . This presentation was made possible by using the suppress option in SPSS. The loading coefficients in this table were calculated with an orthogonal rotation known as Varimax with Kaiser Normalization. 
Table 5. Rotated Component Matrix.

\begin{tabular}{|c|c|c|c|c|}
\hline & & Com & nent & \\
\hline & 1 & 2 & 3 & 4 \\
\hline Internet access & & 0.773 & & \\
\hline Digital skills & & 0.660 & & \\
\hline Digital platforms & & 0.689 & & \\
\hline Comfort on digital platforms & & 0.740 & & \\
\hline Comparing offers on digital platforms & & 0.772 & & \\
\hline Varied offer of products and services on digital platforms & & 0.772 & & \\
\hline $\begin{array}{c}\text { Easy access to information from around the } \\
\text { world for products }\end{array}$ & & 0.780 & & \\
\hline Lower costs through more direct buyer seller contact & & 0.672 & & \\
\hline Access to goods without ownership & 0.608 & & & \\
\hline Access to second-hand goods at lower costs & 0.614 & & & \\
\hline $\begin{array}{l}\text { Possibility of protecting the environment by } \\
\text { purchasing goods }\end{array}$ & 0.658 & & & \\
\hline Possibility of sharing goods to reduce resource consumption & 0.725 & & & \\
\hline Possibility of recovering part of the investment by selling & 0.574 & & & \\
\hline Possibility of sharing a good to reduce financial effort & 0.726 & & & \\
\hline Possibility of recovering part of the investment by renting & 0.587 & & & \\
\hline Possibility of capitalizing on excess owned resources & 0.674 & & & \\
\hline Sharing to increase resource efficiency & 0.703 & & & \\
\hline Sharing spaces for professional activity & 0.674 & & & \\
\hline Common use of electric scooters & 0.686 & & & \\
\hline Decreasing consumption through the shared use of goods & 0.802 & & & \\
\hline Reducing losses costs through the shared use of goods & 0.780 & & & \\
\hline Car-sharing to protect the environment & 0.616 & & & \\
\hline The need to reduce waste & 0.552 & & & \\
\hline Care for the environment & 0.518 & & & \\
\hline $\begin{array}{l}\text { Development of the green economy } \\
\text { through sharing economy }\end{array}$ & & & 0.613 & \\
\hline Postpone the purchase of your own car for at least a year & & & & 0.869 \\
\hline $\begin{array}{l}\text { Did the possibility to benefit from car sharing } \\
\text { persuade you ...? }\end{array}$ & & & & 0.851 \\
\hline $\begin{array}{l}\text { Do you think crowdsourcing can support the } \\
\text { development of a green ...? }\end{array}$ & & & 0.780 & \\
\hline Do you think that an application, such as Waze, can ... ? & & & 0.738 & \\
\hline $\begin{array}{c}\text { Do you think that crowdsourcing can support the } \\
\text { realization of...? }\end{array}$ & & & 0.837 & \\
\hline Do you think that crowdsourcing can achieve the ...? & & & 0.727 & \\
\hline
\end{tabular}

Source: Made by the authors in SPSS. Extraction Method: Principal Component Analysis. Rotation Method: Varimax with Kaiser Normalization. Rotation converged in six iterations.

In the first component we have 16 variables with loading greater than 0.50 and without any negative loading. This means that the correlation between the variables is directed in the same way. The component of digitalization is described by eight variables with very high loadings. The lowest loading for the second component is 0.66 . The third component, 
the green economy, includes five variables, also with very high loadings. The fourth component, environmental protection, includes only two variables with loadings higher than 0.850 .

As a result, we can conclude that with the help of the factor analysis we have been able to reduce the design from 31 variables to four components which explain more than $63 \%$ of the variance of the analysed variables.

\section{Discussion}

According to this result we can conclude that the sharing and the green economies have many common influencing factors and that these two modern economic concepts are supported mainly by the young generation, which is oriented to protect the environment more than the older generation. For the development of the sharing economy, we need digital skills and openness. These abilities also belong to the younger generation.

The third component resulting from the application of the factor analysis indicates the link between the sharing and green economies through the common factors that characterize the two types of economic innovation. The third component, which mainly includes the variables related to crowdsourcing and those related to the interdependence between the sharing and the green economies, confirms the $\mathrm{H} 1$ research hypothesis.

The five variables that make up component three and the values obtained by them are presented below:

1. Development of the green economy through the sharing economy (0.613).

2. Crowdsourcing can support the development of a green economy (0.780).

3. Applications, such as Waze, can reduce traffic congestion and thus reduce pollution (0.738).

4. Crowdsourcing can support smart projects that reduce pollution (0.837).

5. Crowdsourcing can be used to design smart homes that provide a greener way of life (0.727).

These five variables present specific elements of the sharing economy that can have a positive influence on the development of the green economy. On the other hand, component one contains the specific factors that determine the development of the sharing economy. Of the 16 factors included in component one, six are determining factors for the development of the green economy. As a result, we can say that when our behaviour is oriented towards the sharing economy it is a favourable basis for the development of the green economy.

The eight factors concentrated in component two, digitalization, confirm the dependence of the sharing economy on access to modern technology and, of course, the ability to use it. This dependence is mentioned in the literature studied. Jorge-Vázquez points out that digital technologies have stimulated the development of the sharing economy by providing access to an innovative economy for a very large number of participants [1]. Research hypothesis H2 - support for the sharing economy is influenced by the degree of digitalization-is confirmed by the eight factors concentrated in component two.

Regarding hypothesis H3, if we refer to component four, we cannot say that it was confirmed or refuted by the results obtained. The two elements that make up component four are related to the purchase or postponement of the purchase of your own car due to the options and alternatives offered by the sharing economy. These are insufficient bases for a clear conclusion. The variance explained by component four is the smallest of the statistical model obtained in SPSS, namely, $4.283 \%$. Other aspects related to the relationship between the sharing economy and the need to save are found in 10 of the 16 factors that describe component one. The variance explained by component one is the largest, namely, $45.641 \%$. Taking the first component and the fourth component together, we can clearly state that $\mathrm{H} 3$ is also confirmed by the results of our empirical research. These results confirm that, even for our respondents, one of the most important elements of the sharing economy is related to the possibility of saving. This result confirms what we put forward in both the introduction and the literature review, namely, that one of the main elements that favoured 
the development of the sharing economy was the need to make savings to cope with the hurdles from the last 20 years, including the current COVID pandemic crisis [1-3].

One advantage of this innovative economy is that of ensuring sustainability in difficult, uncertain and ever-changing socio-economic and political contexts. In a normal context, the possibility of purchases and the exchange of products carried out in the virtual environment with the support of digital platforms represents for the vast majority of participants in this economy an advantage in terms of comfort, convenience of purchase, the possibility to compare offers, a wide variety of products and easy access to products and services around the world. In the context of the pandemic, it was for many people the only way to continue business and for a number of customers the only way to obtain necessary and desired products and services.

Apart from the strictly economic elements related to the exchange of products or services, digital platforms represented, in the context of the pandemic, a way to continue and exercise the need for socialization and communication in general. Both the recent studies and the results of the primary research carried out highlighted the fact that the number of hours spent by each person in the virtual environment has increased exponentially. In addition, the number of users of digital tools and platforms has increased. This is another very important element that emphasizes the chances for sustainable development through the sharing economy.

Man is a social being and faced with the imposition of physical social distancing he resorted to solutions for communication and the development of private and professional relationships as far as possible in the virtual environment. Even if the virtual environment has supported and replaced for a certain period people's need for communication and socialization, in the long run it cannot be the only solution. It can be only a complementary environment to maintain and develop interpersonal relationships in situations where there is physical distance. The sharing economy is a solution to complete and develop new and innovative branches of a country's economy. It also has important advantages in terms of respecting, protecting and maintaining a healthier and safer natural environment for all people. Restricting consumerism and waste through the tools offered by innovative economies, such as the sharing economy, gives us the possibility to develop new and safe economic branches that ensure necessary goods without unnecessary waste of resources.

\section{Conclusions}

The concept of an economy based on modern technological achievements is accepted and positively interpreted by the participants in this research. At the same time, the analysis of the answers obtained revealed that the ideas of the sharing and the green economies are not widespread, especially among the senior population, which values property and prefers to own a product exclusively and does not have a special interest in the protection of the environment. However, the senior population accepts sharing through the use of services offered by companies that have replaced sales with related services.

A legal and clearly regulated framework of the sharing economy will increase the level of acceptance and, implicitly, increase the safety and trust in the products and services offered. New technologies favour the rapid development of these modern economic forms which have emerged in the last fifteen years. The openness of Romania to the IT industry and the high level of economic growth in our country is an advantage for the development of these new economies.

Regarding consumers in the context of the sharing economy, we can see that those who benefit from its advantages are generally young, educated and with good incomes. Inequality of opportunity due to lack of material resources, digital skills and Internet access is a limitation of the possibilities to develop this type of economy in less developed countries without a national digitalization plan. In our country, Romania, digitalization has experienced a great acceleration in the last nineteen months. This phenomenon was due to the COVID pandemic. Accelerated digitalization was also possible due to our country's outstanding quality of Internet services paired with its low costs. 
Another conclusion of the study is the need for the future development of alternative economic models, which will provide more flexibility, stability and profitability in crisis situations, such as the one caused by the current pandemic. In order to develop such models, a close collaboration between the economic community, governments, local and national institutions and universities and research institutions is necessary in order to determine the most important and viable solutions. For the new models, the legal framework in which they can operate and develop for the benefit of the national economy must also be taken into account.

As our study reveals, digitalization as well as inclination towards saving are factors impacting both the propensity towards sharing, as well as the green economy. In fact, as our findings point out, the demarcation line between the sharing and the green economies is rather fluid, the two realities being under a reciprocal influence. In our model, the green economy develops on the premises of the sharing economy, going a step further in considering the relationship between society and environment, society and sustainable, eco-friendly behaviour. This study can be an important tool and a first step for businesses, and, more importantly, for Romanian public institutions to accelerate the implementation of necessary measures, including legislative ones, in order to promote the further development of these economies.

Although the sharing economy is not necessarily a prerequisite of the green economy, it is, nevertheless, easy for societies or groups that have internalized the lessons of the sharing economy to move forward towards the green economy. It was the ultimate purpose of this research to outline the path of transforming a sharing economy into a green one and to highlight the main factors contributing to this transformation.

One of the main limitations of the present study is that the empirical research lacked people who were unemployed, those without an income or those who have incomes below the national average. Another limitation of this study is the lack of national coverage and the limitation of having respondents from an economic region of our country that is more developed than others. At a later stage, we intend to expand our research with the support of higher educational institutions in our country at the national level. Thus, we intend to see if the results obtained can be generalized over the territory of our country. The study could be extended in countries with high levels of home ownership similar to Romania to determine whether this factor can be an explanation for the development of the two innovative economies, the sharing and the green economies. Another important limitation of the study is the lack of data for the studied variables at different moments in time, for example, before and after the pandemic.

Due to the fact that the focus of the research was on the younger generation and mainly on the population of three major cities in Romania, one limitation of the present research is the low representation of the rural population and of the older population generally. Another limitation is geographical, but the decision to select these three cities was based on the fact that all have a long tradition of preparing the young generation for a better future. The paper enlarges the research area regarding the common factors of the sharing and green economies and the possibilities of finding ways to develop them both.

Author Contributions: Conceptualization, C.V., S.N.V., C.N.C., A.C., M.M., A.-M.M. and I.I.; methodology, C.V., S.N.V. and C.N.C.; software, C.V. and S.N.V.; validation, C.V., S.N.V. and C.N.C.; formal analysis, C.V., A.C., M.M., A.-M.M. and I.I.; investigation, C.V., A.C., M.M., A.-M.M. and I.I.; data curation, C.V., S.N.V., C.N.C., A.C., M.M., A.-M.M. and I.I.; writing-original draft preparation, C.V., S.N.V., C.N.C., A.C., M.M., A.-M.M., C.N.C. and I.I.; writing-review and editing, C.V., S.N.V. and C.N.C.; visualization, C.V.; supervision, S.N.V. and C.N.C. All authors have read and agreed to the published version of the manuscript.

Funding: This research received no external funding.

Institutional Review Board Statement: Not applicable.

Informed Consent Statement: Informed consent was obtained from all subjects involved in the study. 
Data Availability Statement: Not applicable.

Acknowledgments: Not applicable.

Conflicts of Interest: The authors declare no conflict of interest.

\section{Appendix A}

Questionnaire

The sharing and the green economies

1. Please rate, on a scale of 1 to $7(1=$ not at all, $7=$ absolutely $)$, the extent to which the following factors influence your involvement in the collaborative economy (as a buyer/seller/etc.):

a. Internet access;

b. Digital skills;

c. Digital platforms;

d. Comfort on digital platforms;

e. Comparing offers on digital platforms;

f. A varied offer of products and services on digital platforms;

g. Easy access to information from around the world for products and services;

h. Lower costs through more direct buyer-seller contact;

i. Access to goods without ownership;

j. Access to second hand goods with lower cost;

k. Possibility of protecting the environment by purchasing goods with a certain wear;

1. Possibility of sharing goods to reduce resource consumption;

m. Possibility of recovering part of the investment by selling a good with a certain wear and tear;

n. Possibility of sharing a good to reduce the financial effort related to its exclusive possession;

o. Possibility of recovering part of the investment by renting or lending an asset;

p. Possibility of capitalizing on excess owned resources;

q. Sharing to increase resource efficiency;

r. Sharing spaces for professional activity;

s. Common use of electric scooters;

t. Decreasing consumption through the shared use of goods;

u. Reducing losses/costs through the shared use of goods;

v. Car-sharing to protect the environment;

w. The need to reduce waste;

x. Care for the environment.

2. Do you think that the collaborative economy can have a beneficial influence on the development of a green economy? Rate on a scale of 1 to $7(1=$ not at all, 7 = absolutely).

3. Did being able to benefit from car-sharing cause you to postpone the purchase of your own car for at least a year? Rate on a scale of 1 to 7 ( $1=$ not at all, $7=$ absolutely).

4. Did being able to benefit from car-sharing make you give up your personal car? Rate on a scale of 1 to 7 ( $1=$ not at all, $7=$ absolutely $)$.

5. Do you think that crowdsourcing can support the development of a greener economy? Rate on a scale of 1 to 7 ( $1=$ not at all, $7=$ absolutely).

6. Do you think that an application, such as Waze, can reduce traffic congestion and thus reduce pollution? Rate on a scale of 1 to $7(1=$ not at all, $7=$ absolutely).

7. Do you think that crowdsourcing can support smart projects that reduce pollution? Rate on a scale of 1 to 7 ( $1=$ not at all, $7=$ absolutely).

8. Do you think that crowdsourcing can be used, for example, to design smart homes that provide a greener way of life? Rate on a scale of 1 to $7(1=$ not at all, $7=$ absolutely $)$.

9. Gender: male or female. 


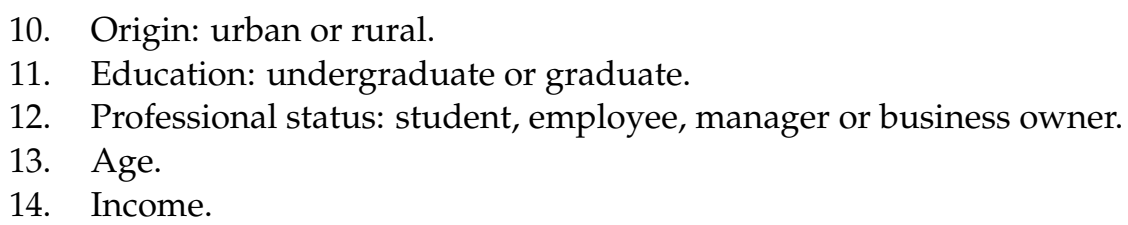

\section{References}

1. Jorge-Vázquez, J. La economía colaborativa en la era digital: Fundamentación teórica y alcance económico. In Economía Digital y Colaborativa: Cuestiones Económicas y Jurídicas; Náñez, S.L., Ed.; Università degli Studì Suor Orsola Benincasa: Naples, Italy, 2019; ISBN 9788896055915. Available online: https:/ / cutt.ly/YEZXeP0 (accessed on 5 December 2021).

2. Jorge-Vázquez, J.; Náñez-Alonso, S.; Ramos, F. La economia colaborativa en el sector de la movilidad y el transport: Hancia la configuracion de un modelo sostenible. In Proceedings of the XVIII Congreso Internacional de Investigadores en Economía Social y Cooperativa La Economía Social: Herramienta para El Fomento del Desarrollo Sostenible y la Reducción de las Desigualdades, Mataró, Barcelona, 17-18 September 2020; Available online: https://www.researchgate.net/publication/34 4869429_LA_ECONOMIA_COLABORATIVA_EN_EL_SECTOR_DE_LA_MOVILIDAD_Y_EL_TRANSPORTE_HACIA_LA_ CONFIGURACION_DE_UN_MODELO_SOSTENIBLE (accessed on 5 December 2021).

3. Selloni, D. New Forms of Economies: Sharing Economy, Collaborative Consumption, Peer-to-Peer Economy. In CoDesign for Public-Interest Services; Selloni, D., Ed.; Springer: Cham, Switzerland, 2017; pp. 15-26. [CrossRef]

4. Lyaskovskaya, E.; Khudyakova, T. Sharing Economy: For or against Sustainable Development. Sustainability 2021, $13,11056$. [CrossRef]

5. Urbach, N.; Ahlemann, F. IT Management in the Digital Age-A Roadmap for the IT Department of the Future; Springer Nature: Cham, Switzerland, 2019; ISBN 978-3030071509.

6. Iacob, V. România Rămâne Țara Cu Cei Mai Mulți Proprietari De Locuințe Din UE. Available online: https://ziare.com/ proprietate/romania-tara-cei-mai-multi-proprietari-locuinte-ue-1717737 (accessed on 5 December 2021).

7. Sofianu, C. Economia Colaborativă_Evoluție Și Tendințe. 2020. Available online: https://economie.hotnews.ro/stiri-fiscalitatea_ la_zi-23753420-economia-colaborativa-evolutie-tendinte.htm (accessed on 5 December 2021).

8. Oxford Dictionaries. Definition of Sharing Economy. 2015. Available online: https://en.oxforddictionaries.com/definition/ shaing_economy (accessed on 12 December 2019).

9. Codagnone, C.; Biagi, F.; Abadie, F. The Passions and the Interests: Unpacking the 'Sharing Economy'; JRC Science for Policy; Institute for Prospective Technological Studies: Bruxelles, Belgium, 2016. [CrossRef]

10. Matofska, B. What Is the Sharing Economy? 2016. Available online: http://www.thepeoplewhoshare.com/blog/what-is-thesharingeconomy/ (accessed on 26 November 2019).

11. Botsman, R.; Rogers, R. What's Mine is Yours: The Rise of Collaborative Consumption; Harper Collins Bremner: New York, NY, USA, 2014. [CrossRef]

12. Gansky, L. The Mesh: Why the Future of Business Is Sharing; Portfolio: New York, NY, USA, 2010; ISBN 978-1-101-46461-8.

13. Bauwens, R. The political economy of peer production. Post Autistic Econ. Rev. 2006, 37, 3.

14. Ehret, M. The Zero Marginal Cost Society: The Internet of Things, the Collaborative Commons, and the Eclipse of Capitalism. J. Sustainability Mobil. 2015, 2, 67-70. [CrossRef]

15. Ogden, T. No Value. A "Big Think" Look at the Future of Capitalism Fails to Reckon with the Factors That Make Capitalism So Resilient; Stanford Social Innovation Review Fall: Stanford, CA, USA, 2014; Available online: https://ssir.org/book_reviews/entry/no_ value (accessed on 18 December 2020).

16. Sundararajan, A. The Sharing Economy: The End of Employment and the Rise of Crowd-Based Capitalism; MIT Press: Cambridge, MA, USA, 2016; ISBN 978-0262034579.

17. Murillo, D.; Buckland, H.; Val, E. When the sharing economy becomes neoliberalism on steroids: Unravelling the controversies. Technol. Forecast. Soc. Chang. 2017, 125, 66-76. [CrossRef]

18. Schor, J.B.; Attwood-Charles, W. The "sharing" economy: Labor, inequality, and social connection on for-profit platforms. Sociol. Compass 2017, 11, e12493. [CrossRef]

19. Acquier, A.; Daudigeos, T.; Pinkse, J. Promises and paradoxes of the sharing economy: An organizing framework. Technol. Forecast. Soc. Chang. 2017, 125, 116. [CrossRef]

20. Treapăt, L.M.; Gheorghiu, A.; Ochkovskaya, M.A. Synthesis of the Sharing Economy in Romania and Russia. In Knowledge Management in the Sharing Economy. Knowledge Management and Organizational Learning; Vătămănescu, E.M., Pînzaru, F.M., Eds.; Springer: Cham, Switzerland, 2018; Volume 6. [CrossRef]

21. Schor, J.B.; Thompson, C.J. Sustainable Lifestyles and the Quest for Plenitude: Case Studies of the New Economy; Yale University Press: New Haven, CT, USA, 2014; ISBN 9780300192322.

22. Schor, J.B. Debating the sharing economy. J. Self-Gov. Manag. Econ. 2016, 4, 7. [CrossRef]

23. Cheng, M. Sharing economy: A review and agenda for future research. Int. J. Hosp. Manag. 2016, 57, 60-70. [CrossRef]

24. Slee, T. What's Yours Is Mine: Against the Sharing Economy; OR Books: New York, NY, USA, 2017; Available online: https: / / dl.acm.org/doi/book/10.5555/3202254 (accessed on 11 January 2020). 
25. Karatzogianni, A.; Matthews, J. Platform Ideologies: Ideological Production in Digital Intermediation Platforms and Structural Effectivity in the "Sharing Economy". Telev. New Media 2020, 21, 95-114. [CrossRef]

26. Andrei, A.G.; Zait, A. The Sharing Economy in Post-communist Societies: Insights from Romania. In Knowledge Management in the Sharing Economy. Knowledge Management and Organizational Learning; Vătămănescu, E.M., Pînzaru, F.M., Eds.; Springer: Cham, Switzerland, 2018; Volume 6, pp. 39-55. [CrossRef]

27. Teubner, T.; Flath, C.M. Privacy in the Sharing Economy. J. Assoc. Inf. Syst. 2019, 20, 2. [CrossRef]

28. Hawlitschek, F.; Notheisen, B.; Teubner, T. The limits of trust-free systems: A literature review on blockchain technology and trust in the sharing economy. Electron. Commer. Res. Appl. 2018, 29, 50-63. [CrossRef]

29. Puschmann, T.; Alt, R. Sharing Economy. Bus. Inf. Syst. Eng. 2016, 58, 93-99. [CrossRef]

30. Porter, M.E.; Kramer, M.R. Creating Shared Value-How to Reinvent Capitalism-And Unleash a Wave of Innovation and Growth. In Managing Sustainable Business; Lenssen, G., Smith, C.N., Eds.; Springer: Dordrecht, The Netherlands, 2019 ; pp. 323-346. [CrossRef]

31. Lakatos, E.-S.; Nan, L.-M.; Bacali, L.; Ciobanu, G.; Ciobanu, A.-M.; Cioca, L.-I. Consumer Satisfaction towards Green Products: Empirical Insights from Romania. Sustainability 2021, 13, 10982. [CrossRef]

32. Sulich, A. The Green Economy Development Factors. In Proceedings of the 32nd IBIMA Conference-Vision 2020: Sustainable Economic Development and Application of Innovation Management, Seville, Spain, 15-16 November 2018; pp. 6861-6869. Available online: https:/ / www.researchgate.net/publication/330620155 (accessed on 5 December 2021).

33. Arnedo, E.G.; Valero-Matas, J.A.; Sánchez-Bayón, A. Spanish Tourist Sector Sustainability: Recovery Plan, Green Jobs and Wellbeing Opportunity. Sustainability 2021, 13, 11447. [CrossRef]

34. Rashid, H.U.; Zobair, S.A.M.; Shadek, J.; Hoque, A.; Ahmad, A. Factors Influencing Green Performance in Manufacturing Industries. Int. J. Financ. Res. 2019, 10, 159. [CrossRef]

35. Cebolla, M.P.C.; Vázquez, J.J.; Cebolla, C.M.C. Collaborative economy, a society service? Involvement with ethics and the common good. Bus. Ethics Environ. Responsib. 2021, 30, 657-674. [CrossRef]

36. Junnila, S.; Ottelin, J.; Leinikka, L. Influence of Reduced Ownership on the Environmental Benefits of the Circular Economy. Sustainability 2018, 10, 4077. [CrossRef]

37. Grinevich, V.; Huber, F.; Karatas-Ozkan, M.; Yavuz, Ç. Green entrepreneurship in the sharing economy: Utilising multiplicity of institutional logics. Small Bus. Econ. 2019, 52, 859-876. [CrossRef]

38. Boar, A.; Bastida, R.; Marimon, F. A Systematic Literature Review. Relationships between the Sharing Economy, Sustainability and Sustainable Development Goals. Sustainability 2020, 12, 6744. [CrossRef]

39. Karobliene, V.; Pilinkiene, V. The Sharing Economy in the Framework of Sustainable Development Goals: Case of European Union Countries. Sustainability 2021, 13, 8312. [CrossRef]

40. Han, J.; Chen, X.; Sun, Y. Technology or Institutions: Which Is the Source of Green Economic Growth in Chinese Cities? Sustainability 2021, 13, 10934. [CrossRef]

41. De Felice, F.; Petrillo, A. Green Transition: The Frontier of the Digicircular Economy Evidenced from a Systematic Literature Review. Sustainability 2021, 13, 11068. [CrossRef]

42. Townsend, J.H.; Coroama, V.C. Digital Acceleration of Sustainability Transition: The Paradox of Push Impacts. Sustainability 2018 10, 3816. [CrossRef]

43. Saraji, M.K.; Streimikiene, D.; Kyriakopoulos, G.L. Fermatean Fuzzy CRITIC-COPRAS Method for Evaluating the Challenges to Industry 4.0 Adoption for a Sustainable Digital Transformation. Sustainability 2021, 13, 9577. [CrossRef]

44. Kormishkina, L.A.; Kormishkin, E.D.; Sausheva, O.S.; Koloskov, D.A. Economic Incentives for Environmental Investment in Modern Russia. Sustainability 2021, 13, 11590. [CrossRef]

45. Florea, N.V.; Duică, M.C.; Ionescu, C.A.; Duică, A.; Ibinceanu, M.C.O.; Stanescu, S.G. An Analysis of the Influencing Factors of the Romanian Agricultural Output within the Context of Green Economy. Sustainability 2021, 13, 9649. [CrossRef]

46. Alsarhan, L.M.; Alayyar, A.S.; Alqahtani, N.B.; Khdary, N.H. Circular Carbon Economy (CCE): A Way to Invest CO 2 and Protect the Environment: A Review. Sustainability 2021, 13, 11625. [CrossRef]

47. Hair, J.F., Jr.; Black, W.C.; Babin, B.J.; Anderson, R.E. Multivariate Data Analysis: A Global Perspective; Pearson: London, UK, 2010; ISBN 0135153093.

48. Sreejesh, S.; Mohapatra, S.; Anusree, M.R. Business Research Methods-An Applied Orientation; Springer: Cham, Switzerland, 2014; ISBN 978-3-319-00539-3

49. Cărbureanu, M. A factor analysis method applied in development field. Ann. -Econ. Ser. 2010, 1, 187-194.

50. Tussyadiah, I.P. An exploratory study on drivers and deterrents of collaborative consumption in travel. In Information and Communication Technologies in Tourism 2015; Tussyadiah, I., Inversini, A., Eds.; Springer: Cham, Switzerland, 2015; pp. 817-830. [CrossRef]

51. Bellotti, V.; Ambard, A.; Turner, D.; Gossmann, C.; Demkova, K.; Carroll, J.M. A Muddle of Models of Motivation for Using Peer-to-Peer Economy Systems. In Proceedings of the CHI '15: CHI Conference on Human Factors in Computing Systems, Seoul, Korea, 18-23 April 2015; p. 1085.

52. Eurobarometer. The Use of Collaborative Platforms; Publications Office: Luxembourg, 2016; Volume 438, Available online: http:/ / ec.europa.eu/COMMFrontOffice/publicopinion/index.cfm/Survey/getSurveyDetail/instruments/FLASH/surveyKy/2112 (accessed on 5 December 2021). 
53. ING Group. What's Mine Is Yours-For a Price. Rapid Growth Tipped for the Sharing Economy. 2015. Available online: https: //www.slideshare.net/ING/sharing-economy-ing-special-report (accessed on 8 February 2020).

54. PricewaterhouseCoopers LLP (PwC). The Sharing Economy; Consumer Intelligence Series; PricewaterhouseCoopers LLP: London, UK, 2015; Available online: https://www.pwc.com/us/en/industry/entertainment-media/publications/consumer-intelligenceseries/assets/pwc-cis-sharing-economy.pdf (accessed on 5 December 2021).

55. Smith, A. Shared, Collaborative and on Demand: The New Digital Economy; Pew Research Centre: Washington, DC, USA, 2016; Available online: http:/ / www.pewinternet.org/2016/05/19/the-new-digital-economy/ (accessed on 12 May 2020).

56. Schor, J.B.; Fitzmaurice, C.; Carfagna, L.B.; Attwood-Charles, W.; Poteat, E.D. Paradoxes of openness and distinction in the sharing economy. Poetics 2016, 54, 66-81. [CrossRef]

57. Andreotti, A.; Anselmi, G.; Eichhorn, T.; Hoffmann, C.P.; Micheli, M. Participation in the Sharing Economy: Report from the EU H2020 Research Project Ps2Share: Participation, Privacy, and Power in the Sharing Economy; European Union's Horizon: Bruxelles, Belgium, 2020; Available online: https://www.academia.edu/32730292/Participation_in_the_Sharing_Economy?auto=download\&email_ work_card=download-paper (accessed on 11 May 2020).

58. Deloitte. The Sharing Economy: Share and Make Money: How Does Switzerland Compare? 2015. Available online: https: //www2.deloitte.com/ch/en/pages/consumer-business/articles/the-sharing-economy.html (accessed on 5 December 2021).

59. Ipsos. TOPSHARING: Ipsos è nell'Era della Sharing Economy ... e tu? 2017. Available online: http://www.ipsos.it/newseventi/topsharing-ipsos-\%C3\%A8-nell\%E2\%80\%99era-della-sharing-economy\%E2\%80\%A6-e-tu (accessed on 5 December 2021).

60. Van Dijk, J. The Deepening Divide: Inequality in the Information Society; Sage: London, UK, 2005. [CrossRef] 